\title{
God accepts a broken spirit and a contrite heart - Thoughts on penitence, forgiveness and reconciliation in Psalm 51
}

D J Human

(University of Pretoria)

\section{ABSTRACT}

God accepts a broken spirit and a contrite heart - Thoughts on penitence, forgiveness and reconciliation in Psalm $\mathbf{5 1}$

A concern with reconciliation amidst broken relationships permeates the religious discourse of human spirituality. In addition, in the history of Christian spirituality in particular, the role of penitence has been considered to be an integral part of authentic faith in a fallen world blighted by sin. With this as background, the present article discusses the biblical text of Psalm 51, a poignant and dramatic rendering of a sinner's penitence in his quest for forgiveness and reconciliation. Acutely aware of his transgressions, the psalmist confesses his own sinfulness whilst acknowledging the divine requirement of genuine repentance and complete dependence on God's grace. With these thoughts, Psalm 51 also allows the reader to discover for him/ herself the process of repentance - penitence - forgiveness - renewal and, ultimately, reconciliation.

\section{INTRODUCTION}

Relationships between people are fragile. These are bound together with the thin strings of the human spirit; that is why relationships are so easily shattered. When someone is guilty of damaging a relationship or causing its demise, it is difficult to simply pick up the pieces and make them fit together once more. Wrong actions can inflict gaping wounds in any healthy relationship - also in the one between God and his children. Guilt and debt can destroy a relationship.

And yet, throughout the ages, human beings have tried to pick up the pieces of broken relationships. Such a mending of shattered bonds involves the restoration of the meaning of life in the heart and eyes of people; in this manner the human spirit can be reinvigorated and sparked with renewed vitality. When once mutually hostile human hearts are reconciled, the result is harmony, peace and joy. However, to 
reach that goal it is necessary to turn around during one's journey through the fast flowing river of life and its cragged rocks and to cross the whirlpool and tread on the stepping stones of penitence and forgiveness. Only then will one be able to reach the banks of reconciliation on the other side where God and neighbour await one as fellow travelers. In this way one can emerge from the murky and miserable waters of sadness to take on life once more and with renewed confidence and vigour.

In order to look at this process of turning - penitence forgiveness - renewal from the eyes of an Old Testament poet we shall use Psalm 51 as our point of departure. This psalm is known as the 'Great Psalm of Penitence'. In this psalm the believer may discover new light in attaining relief from the burden of guilt in the relationship with God and in the attempt to renew one's vitality.

\section{TO DO PENANCE}

To do penance simply means to pay one's debt. This can be done by paying a fine that removes the debt, so that the guilty person is no longer such. Instead he/she finds him/herself as one who is now innocent before the law. However, doing penance can also involve more than simply paying a fine. To be sure, it can also denote a process consisting of various phases, which includes turning to someone/God, the acknowledgement of guilt, to ask for forgiveness, to pray to God for renewal, or and to show gratitude in order to live in communion or reconciliation with someone/God.

In the relationship between God and people, the wrong actions leave one to become guilty before God. We may call this sin. Sin in this context refers to the attitude of opposing all the activities of God, not acknowledging Him, and doing what is not His will. In other words, to sin means to move further and further away from God in the journey of one's life. It amounts to a kind of alienation that becomes visible in the attitudes and acts of people.

The Old Testament knows of more than one way in which this kind of guilt of people in relation to God can be removed: first, through sacrifice and second, through an inner willingness to oppose evil actions through sorrow and turning to God (Vorgrimler 2000:106). 
For the ancient Israelite penance was linked to a deed of sacrifice (Welten 1981:434). When different kinds of sin - and guilt sacrifices were made to God at the altar, the shedding of the blood of the sacrificial animal means that the guilt of the guilty party (parties) is recompensed through the life of another. This 'other' life ordinarily came from the bird and animal kingdoms. According to the laws of Moses in the Pentateuch, it is clear that God accepted this payment, even if it was of less value than the guilt or the life of the guilty person. This already confirmed God's great love and mercy. His ensuing forgiveness meant that the healthy relationship between God and the guilty person was mended once more.

It is important to note that forgiveness of sins cannot be seen in the Old Testament and especially in the Psalms as an isolated issue. Forgiveness is always part of the total concept of God's salvation (McKeating 1965:69).

As noted above, the process of penance can also occur through the inner opposition to sin and a deliberate turning to God. The sinner's sorrow over his/her evil actions along with the inner mourning and repentance make an appeal to God's forgiveness. This conversion to God means that the guilty individual anchors his/her attitude to life once more and redirects the inner disposition once again to the love of God. Through this act the sinner acknowledges that God is able to grab hold and initiate transformation on all levels of his/her life. For this reason the sinner distances him/herself from the wrong actions in the present and the past and moves ever closer to the presence and nearness of God.

In the poetic texts of the Old Testament we see how the guilt, sorrow, forgiveness and reconciliation that the faithful experience come to the fore in a special manner in the psalms of prayer.

\section{DOING PENANCE: A KALEIDOSCOPE OF WAYS}

In the tradition of the Christian Church there is more than one way in which penitence can be expressed. In the practice of being the Church and being a Christian, it might include the following (see Vorgrimler 2000:106):

- When people from both outside and inside the Church listen to the preaching and exposition of the Bible, and their own 
importance and vanity are critically addressed in this manner, they can respond to such judgment through prayer. Prayer is one way in which a believing sinner can communicate with, and open his/her heart to, God. In this manner the believer's experiences of guilt, sorrow, and penitence can be articulated;

- When the relationship between believers are troubled, the guilty party can restore harmony through compensating for the damage caused (restitution) (cf. Mt 5:23);

- Through the practical living of divinely inspired love someone can once more move closer to God in the aftermath of a once alienated relationship with the Lord;

- $\quad$ Penance can be done in a dialogue by which someone indicates and acknowledges his/her sinful actions;

- In some traditions of the Christian Church, penance can be done via asceticism. In this method some believers withhold from themselves the fulfillment of joy, sexual pleasure or other sensual human needs. This manner of doing things does not mean, however, that they can manipulate God with their deeds or accomplishments so that He is forced to forgive them. Rather, the ascetic lifestyle is a means whereby people deny themselves some things so that they may focus more fully on themselves and their inner life. In this way they meditate on their sorrow for their sinful actions;

- $\quad$ The Church represents a sacred space in which reconciliation between both God and people and between people themselves can be actualised. Particularly liturgical and symbolic acts in the Church contribute to this process. The participation in the sacraments is a ritual that simbolises the mercy of God. It confirms that reconciliation occurs between God and people on a variety of levels: The water of baptism emphasises the belief that God washed away the sin or guilt that people carry in relation to Him and others. With Holy Communion (the Lord's Supper) the symbols of bread and wine call into remembrance the death and resurrection of Jesus according to the Gospels. Once again, this sacrament concretely depicts the reconciliation when it signifies the restoration of the broken relationship between God and 
people. In some Christian traditions, the sacraments of penitence and the anointing of the sick have a special significance in connection with this purpose. Both these sacraments allow believers to participate symbolically in the healing and recovery of their relationship with God in which there may be present guilt or suffering.

Thus there exist several ways in which the faithful of the different Christian traditions can participate in the process of doing penance. To appreciate, however, how the experiences of the ancient psalmist(s) can contribute hereto, it is necessary to look inside the hearts of these poets. Subsequent to a couple of introductory thoughts on the so-called 'Psalms of Penitence' of the Old Testament vis-à-vis their ancient Near Eastern environment, we shall look at Psalm 51 as a practical example. In this manner we wish to discover what lies at the heart of the repentant believer and community. This experience can assist us in finding the appropriate words when we divulge our own hearts in similar circumstances before God and our fellow humans.

\section{PSALMS OF PENITENCE}

The Psalms of the Old Testament are part of ancient Near Eastern literature. These poetic texts reflect the words, imagery and imaginations of their environment. Israel's neigbouring cultures, e.g. the Sumerians, Assyrians and Babylonians, also left us many examples of rituals and prayers of penitence (Fischer 1958:822). The essence of these prayers and rituals was most often a crisis situation in which the king, the people or an individual found himself or herself. The cause of the crisis was some kind of conscious or unconscious transgression perpetrated by those who subsequently suffer. Consequently, these unfortunates yielded themselves to prayer and/or rituals to appease one or more of the gods with the request that their sins may be forgiven and for the removal of their punishment.

In Israel, there were similar prayers of penitence. These prayers were aimed at the one God, Yahweh, Israel's only God. These were used in the cult, or in Israel's places of prayer, mainly in the context and framework of the lament or the lamentsong. Both the individual 
pious believer and groups of the faithful among the people of Israel prayed these prayers (Olivier en Swanepoel 1997:201-214).

Prayers of penitence are not limited to the Psalter. There exist several familiar prayers of penitence outside of this book (cf. Is 59:915; 64:4-12; Jr 3:22-25; 14:7ff and 19-22; Hs 6:1-3; Mi 7:9-20; $1 \mathrm{Ki}$ 8:33-44; Ezk 9:6-15; Neh 9:26-37; Dn 9:4-19). In these poems, those who pray divulge the sighs of their hearts to God.

A variety of elements of this kind of prayer is noticeable upon listening to its expression: the confession of guilt and unfairness before God plays an important role (Ps 106:6); the one praying struggles with his own sin, he is trapped in his own guilt (Pss 6; 38; 69; 143); there is a plea for forgiveness and the removal of sin (Pss 51; 130); the psalmist sometimes center his thoughts on debt, confession of sin and forgiveness by way of retrospection (Ps 32:1,5). Especially the sorrow displayed by those who pray shows that their hearts are open to God and that they are intensely aware of their guilty standing before Him.

Even though the lament is the primary means through which those in prayer do penance before God, it is nonetheless not the only kind of text in which elements of penitence appear. There is also the song of thanksgiving (Ps 32). In this song, the psalmist(s) thanks God before other believers for his forgiveness. God and his community are both addressed in the thanksgiving. The community is called to praise God for his act of salvation.

The lament contains a number of basic elements that make it appropriate for doing penance: the one in prayer calls on God in the midst of his crisis; then he laments his need before the Lord; the need is then gradually articulated; the one in need then prays for deliverance from this condition; eventually he confesses also his trust in this God who provides salvation; ultimately, the one praying reaches the point where he praises and/or thanks the Lord for his loyal love and for the deliverance He provides. Not all of these elements appear of necessity in every single song of lamentation; ultimately, the particular situation of the one praying determines the form in which the psalmist casts his prayer. 


\section{A MEDIAEVAL LITURGICAL TRADITION}

At present, seven psalms are considered to be psalms of penitence in the Christian tradition due to their nature and contents, namely Psalms 6, 32, 38, 51, 102, 130, 143 (Press 1969:276; Gispen ea 1975:168). The origin of this particular choice comes from a liturgical tradition that dates back to the early mediaeval period. It is roughly in the sixth century that Cassiodorus refers for the first time to these seven psalms as a group (Murphy 1967:85; Bardtke 1989:1085).

Cassiodorus understood the number seven allegorically or figuratively. He reckoned that the number symbolised seven ways in which one might receive forgiveness. In this regard, he mentions baptism, martyrdom, alms, a forgiving spirit, repentance of the sinner, love and chastisement. Before his death, Augustine allowed the setting of some of the psalms of penitence right in front of his grave.

In response to the command of several popes, these psalms were prayed in the Roman Catholic Church during periods of fasting. They were also utilised within the Christian Church in general. Psalm 51 is known as the so-called Miserere (Weber 2001:236) while Psalm 130 as De Profundis. Apart from the fact that these psalms are considered by the Christian Church to be classic prayers for confessing one's guilt, they are also recited during the devotion of a church, the anointing of the sick, as well on a variety of occasions during ordinary worship services.

Besides Psalm 32, which is a song of thanksgiving (Weber 2001:158), the remaining six psalms all have the characteristics of a lament. Each of these psalms also has an individual character but, due to their history as a group of psalms, they have also attained collective meaning. In all these prayers we hear the repentant sinner's pleas that the Lord may free him from his enormous burden of guilt and sin. Only in one prayer does the matter of restitution clearly come to the fore, namely in Psalm 51. That is why we shall now concern ourselves with a more in-depth analysis of this psalm. 


\section{PSALM 51 - A PRAYER FOR PENITENCE}

\subsection{Introduction}

Psalm 51 is known as the 'Great Penitential Psalm'. It is a prayer to God for the forgiveness of sins. In view of his sin the psalmist begs God to renew his life once more. He asks the Lord to restore their relationship, which has been overwhelmed by guilt and sin. For that he is willing to pay - with praise, a broken spirit and a contrite heart.

Psalms 51-72 is known as the second collection of Davidic psalms (Pss 51-72), that consists of songs of lamentation (Pss 51-64), hymns and songs of thanksgiving (Pss 65-68) as well as a mixture of songs that concludes the collection (Pss 69-72) (see Millard 1994:115124). The characteristics of the text are very reminiscent of the lament of the individual (Deissler 1964:208; Terrien 2003:402), although the contents of Psalm 51 reflect features of a song of penitence. Various elements of this lament song are recognisable: In his need the psalmist calls to God; his situation of need is clearly articulated - sin and guilt are destroying his life; then the psalmist begs for salvation and renewal; even the psalmist's trust in God comes to the fore; elements of praise are also clearly visible.

\subsection{Segmentation and translation}

The Hebrew text of Psalm 51 is well preserved. Based on considerations regarding the language, style and contents of the psalm, we may divide the song into five individual subsections (Hossfeld \& Zenger 2002:333). Each of these subsections has a specific and special function in the articulation and reconstruction of the psalmist's experience of penitence. The division appears as follows:

- Heading (1-2)

- Call on God and a confession of guilt (3-7)

- Begging for renewal and the forgiveness of sins (8-14)

- Promise to give praise and thanks (15-19)

- Prayer to restore Zion (20-21)

The following translation from the New International Version (NIV) will allow for a more user-friendly guidance of the reader through the discussion below. The indication of verse numbers in brackets reveals 
the division of these verses as found in the Hebrew Bible. The present division is done accordingly.

${ }^{(1) 1}$ For the director of music. A psalm of David.

(2) When the prophet Nathan came to him after David had committed adultery with Bathsheba.

(3) Have mercy on me, O God, according to your unfailing love; according to your great compassion blot out my transgressions.

(4) 2 Wash away all my iniquity and cleanse me from my sin.

(5) 3 For I know my transgressions, and my sin is always before me.

(6) 4 Against you, you only, have I sinned and done what is evil in your sight, so that you are proved right when you speak and justified when you judge.

(7) 5 Surely I was sinful at birth, sinful from the time my mother conceived me.

(8) 6 Surely you desire truth in the inner parts; you teach me wisdom in the inmost place.

(9) 7 Cleanse me with hyssop, and I will be clean; wash me, and I will be whiter than snow.

(10) 8 Let me hear joy and gladness; let the bones you have crushed rejoice.

(11) 9 Hide your face from my sins and blot out all my iniquity.

(12) ${ }^{10}$ Create in me a pure heart, O God, 
and renew a steadfast spirit within me.

(13) 11 Do not cast me from your presence

or take your Holy Spirit from me.

(14) 12 Restore to me the joy of your salvation

and grant me a willing spirit, to sustain me.

(15) 13 Then I will teach transgressors your ways,

and sinners will turn back to you.

(16) ${ }^{14}$ Save me from bloodguilt, $O$ God, the God who saves me,

and my tongue will sing of your righteousness.

(17) 15 O Lord, open my lips,

and my mouth will declare your praise.

(18) ${ }^{16}$ You do not delight in sacrifice, or I would bring it;

you do not take pleasure in burnt offerings.

(19) 17 The sacrifices of God are a broken spirit;

a broken and contrite heart, O God, you will not despise.

(20) ${ }^{18}$ In your good pleasure make Zion prosper;

build up the walls of Jerusalem.

(21) 19 Then there will be righteous sacrifices,

whole burnt offerings to delight you;

then bulls will be offered on your altar.

\subsubsection{Heading (1-2)}

The heading immediately connects this psalm to the story of David and Bathsheba in 2 Samuel 11-12. In particular verses 3a ("Have mercy on me, O God, according to your unfailing love” - cf. 2 Sm 12:22), 6a (“Against you, you only, have I sinned" - 2 Sm 12:13) en 19 ("The sacrifices of God are a broken spirit; a broken and contrite heart, O God, you will not despise" - cf. 2 Sm 12:15-17) connect the psalm to David's history of shame wherein this model king of Israel commits 
adultery and murder; gets his soldier Uriah drunk, ignore the standard protocol of fighting a war; and dismisses the death of his soldier as something insignificant after Uriah died fighting in the front line of the king's army (Tate 1990:12; Hossfeld \& Zenger 2002:335).

In the heading we find not only an allusion to David's great burden of sin and the confession of his sinful deeds. It also calls in remembrance the Lord's merciful forgiveness granted to the model king. In Israel, adultery and murder was committed on pain of death (Lv 20:10; Dt 22:22; Nm 35:30-31). Subsequent to his transgressions, David could not have made recompense to Bathsheba or Uriah. Nor could he restore her purity, or his own life. His burden of guilt implied damnation. He commits the sin in the midst of a war in which he and his army found themselves engaged in (2 Sm 11-12). As is the case with the psalmists of Psalms 52-64, this individual's life is threatened by death, yet God saves him from his seemingly inevitable fate.

Even though the headings to the Psalms are late additions and the fact David was probably not the author of this psalm, the particular introduction to the psalm provides a historical context in which the rest of the psalm can be read sensibly, namely in the 'David community' (Gerstenberger 1988:212). This historical reference is but one example from the life of David and can easily be substituted with a similar albeit different and modern context. In the community of David where the believers are bound to the Lord, God provides forgiveness to his prayerful servant(s) whose lives attest an orientation toward their sins as one of sorrow and repentance.

That the psalm played an important role in the places of prayer in Israel is confirmed by the addition "for the director of music".

\subsubsection{Call on God and a confession of guilt (3-7)}

The psalmist calls to God in the hour of his greatest need. This call emphasises the urgency of his crisis as well as his need for deliverance. That the one praying calls upon God in his time of distress means that he trusts the Lord to guide him through it.

Furthermore, the psalmist wants to emphasis something of God when he calls on Him. He is a merciful God who shows loving kindness and loyalty to the people of his covenant, and this with a heart full of mercy. These attributes were also divulged to the Israelites when he 
forgave them after they betrayed his faith by worshipping the image of a golden calf at Sinai (Ex 34:6-7). There at Sinai God revealed himself to sinful Israel. The psalmist knows this; that is why he makes an appeal to this kind of grace, loyalty and motherly love of the God who had already in history proven himself as loyal partner to his people. It is the God of history, Israel's Covenant God with whom we are dealing with here.

In no uncertain discourse the psalmist construes his crisis. He is guilty before God because of his sin. Nine times within the first seven verses he depicts his lamentable situation before the Lord: it is his unjustness, sin, evil and transgression that he repeatedly lay before God. As David confessed it before the prophet Nathan (2 Sm 12:13), so the psalmist does the same here before God: "Against you, only you, have I sinned" (v 6). He confesses his sin and guilt before God. He admits that he diverted from the Lord whilst traveling on the path of his life through acts of injustice. For him, his sin is not primarily a social matter or hurt caused to his fellow humans; it is an offense to God and a transgression of the divine order.

The psalmist is totally overwhelmed by his condition of sin and guilt. This totality of guilt is emphasised in verse 7 in which he claims that this condition has been his burden from the beginning of his life. He says: "Surely I was sinful at birth, sinful from the time my mother conceived me". Whether by this is meant conception or the physical birth itself is not clear. Whatever the case may be, it is clear that according to the psalmist, even from the beginning of his existence, he was exposed to the power of sin and his life was threatened by it. In the past this verse was called upon to justify and confirm the classical Church (Augustinian) doctrine of inherited sinfulness. From the context of the psalm, however, this interpretation appears to be doubtful. The emphasis, though, falls on the "comprehensive nature of the supplicant's own sin” (Tate 1990:20).

What does the sinner do with his condition of sin? Apart from his confession of guilt he takes it in prayer to the just God with the request to have it removed ("Wash away..." “cleanse me..." v 4). He asks that God may take away the sins, analogous to the way one cleans a dish, or to the manner in which one refines metal through a process of melting it in the fire (cf. Is $1: 16$; Jr 2:22; 4:14). To be able to move 
outside the domain in which sin holds sway means that you must enter the domain of the just God and surrender yourself freely to the judgment of the merciful Lord. This is what he does. In this way we meet God as the just judge.

\subsubsection{Begging for forgiveness and renewal (8-14)}

To God, the evil that comes with guilt and transgression between Him and his suffering servant is unacceptable. He therefore initiates the awareness of guilt in the deepest recesses of the sinner. He plants truth in the heart of the guilty person. This truth includes the fact that the distorted relationship between God and the one at prayer must be healed. Sin and guilt must be removed therefrom. The wisdom that the Lord teaches the sinner is the realisation that sin and guilt is destructive Therefore the sinner, in the awareness of guilt, must turn only to the God of justice.

To enter once more and in a state of purity the Israelite community of the faithful, the guilty person had to enact a symbolic rite of purification (cf Nm 19). A branch of hyssop, a type of herb, was used in the cult as part of a ritual in which the water of purification was sprinkled on the unclean person or object. In this manner he/she was symbolically cleansed. The branch was subsequently used in the cleansing process of a leper enabling him/her to once more become part of the community of believers and be reconciled to God (Lv 14). Leprous people were normally perceived to be unclean and polluted and were driven from the community. When therefore the psalmist prays to God to wash and cleanse him, he is asking God to take away his guilt; to make him part of the His community once more; and to free him from the dark domain of death so that he may once more dwell in the joyful and festive land of the living.

From the requests in the prayer it is clear that sin and guilt are associated with darkness, filth, uncleanness, and the absence of joy. It places the sinner outside the community of believers and he/she must therefore reckon with God's punishment for God can see sin for what it is. The experience of the psalmist that God breaks his bone implies not only a dislocated existence but also God's strong aversion to the injustice that was perpetrated. 
The sinner's prayer involves a yearning for the clean, spotless and joyful life in the living space of Israel's believers. In this community he is accepted once more after his ostracism and absence when he is given a white and unblemished robe of festiveness (Ec 9:8). This life for which the psalmist prays is a life reconciled to God. From such a life, God has removed all sin. God does not dwell upon the guilt any more but averts His gaze. The joy that follows this assumes that forgiveness has been granted. Thus the one at prayer acknowledges in his pleas God as the initiator and giver of this reconciled life.

The psalmist is aware of his own inner moral impotence. He realizes that on his own he will never be able to live a new life. For this his heart and spirit, the basic driving forces of life, are much too dependent on God's own Spirit. Not only God's forgiveness but something new is needed to carry his life to the future. This is why, in the second part of his prayer, the psalmist prays that God must renew his heart and his spirit. It must be a new creation. This is something God alone can do. Then the psalmist will be able to do the Lord's will and to acknowledge the divine order.

In the Old Testament the heart signifies several aspects of human life. Sometimes it refers to a person's personality (Ps 73:26). Elsewhere it denotes the organ with which the intellect (Ps 77:6), memory (1 Sm 1:13), emotion (Ex 4:14), desire (Gn 34:3, 8) and will (Dt 2:20) of humans are expressed. It is with the heart that one thinks. Therefore it is the seat of reason. You can decide whether or not you want to accept God's order for living and open your heart to the Lord (Hossfeld \& Zenger 2002:337). The psalmist asks God for a pure heart, one from which sin is absent. With this plea he begs God to enable him to make the right decisions.

The human spirit is the bearer of human life. God imparted this spirit by blowing the breath of life into man (Gn 2:7). Without it, man cannot live. With it, man partakes in God's life giving spirit. For this reason the psalmist asks for three things: a steadfast spirit (v 12b); the connection with God's holy spirit (v 13b); and a willing spirit (v 14b). This communion with the Spirit of God will enable him to live in God's presence and experience the life and joy that comes with it. 
In this manner God's new creation is synonymous with the salvation he provides the guilt-laden psalmist. This new creation is also the trademark of God's forgiveness.

What God did with Israel in history, he also does for the individual. A collective experience attains individual meaning in this context. The author of Psalm 51 harks back to the work of God and the promises he made to his people Israel and makes it applicable to the praying sinner. In the psalm we hear of various aspects of God's salvific work for his people: there is the forgiveness of sins (Is 43:25; 44:22; Jr 31:31-34); the matter of renewal (Is 43:1-21); the deliverance from exile which brings joy (Is $35: 1,10 ; 51: 3,11$ ); the creation of a pure heart and a new spirit (Ezk 11:14-20; 36:24-28) and the partaking in God's spirit (Ezk 37:1-14). It would appear that the psalmist knew Israel's history within and even after the Babylonian exile. In light of this history he hoped that God would forgive him his sin and guilt.

\subsubsection{Sacrifices of praise and thanks (15-19)}

The renewal that God's forgiveness grants has certain consequences for the life of the psalmist. Not only his relationship with God is different but also with regard to other sinners and transgressors he has a new responsibility. The realisation that God has guided him from the power of death to the joy of life makes him thankful to God. He has a new lease on life because God has averted his bloodguilt, which deserves the death penalty. He has been freed from the sentence of death. This is his motivation for bringing a sacrifice of thanksgiving and to be part of the struggle against the fatal power of sin.

As Moses taught Israel the ways of the Lord (Ex 33:13; 34:4-7), so the psalmist now wishes to instruct those who have turned from God so that they may return to Him. He wishes to help them turn from the pathways of death by showing them God who is merciful, who shows loving kindness and loyalty to his covenant partners and acts with a heart full of mercy. As Judge He will be just as he holds salvific righteousness in His hand. Not only has God already walked this road with Israel but He has also confirmed the assurance to the psalmist that he will continue to do so with other sinners and transgressors.

One of the characteristics of the newly created life is to act from a position of dependence on the Lord. Our psalmist does just that and 
shows this dependence through the expression of his joy and by acknowledging that even the initiative to praise God comes from Him. That is why he is able to ask: "Open my lips, and my mouth will declare your praise".

Because this servant is thankful for his deliverance he wants to bring a sacrifice of thanksgiving to the Lord. In the Israelite community of believers the elements of praise usually belong together with a sacrifice on the altar (Pss 26:6-7; 40:5-8; 43:4; 107:21; Jnh 2:9). But in line with some of the prophets' critique on the sacrifice on the altar (Hs 6:6; Am 5:21-27; Mi 6:8) the thankful and redeemed psalmist intends to bring an altogether different type of sacrifice (Hossfeld \& Zenger 2002:337). In view of David's sorrow and repentance (2 Sm 12:16-21), the author does not bring sacrifices featuring either animals or vegetable produce (Lv 7:11-15; Ps 69:31-32). Instead, this sacrifice will be constituted by “a broken spirit, a broken and contrite heart” (v 19).

In his deepest need the psalmist asks of God a pure heart as well as a sure and willing spirit in connection with God's own spirit (vv 1214). Thus he offers the Lord a broken spirit with a contrite heart as part of a sacrifice of thanksgiving. Following David's example of the way of faith the psalmist presents himself to God. There is a return of his spirit to God's spirit, back to where it originated. In addition, there is the breaking of his own heart and spirit that emphasises his dependence on God. Both his heart and his spirit have shattered. As was the case with David, this act of gratitude comes only from and a deep sense of sorrow before God over his own burden of guilt and sin (cf 2 Sm 12:15-18). The psalmist presents himself as one who is open and available to live a life of communion, that is, a life of faith, with God. And it is this that gives him boundless joy.

With his sacrifice of thanksgiving, which was a broken spirit and a contrite heart a sense of expectancy of and an awaiting the loving, blessing and merciful acts of God is created for the future. The person who brings him or herself in sorrow and repentance to God and in faith can be assured of the future with the Lord who holds the saving righteousness in his hand. Such a person can wait in the hope of the healing and salvific grace, loyal love and mercy of God. 


\subsubsection{Praying for the restoration of Zion (20-21)}

Not only the individual but also God's people can live with this expectation. That is why the psalm ends with a prayer for the future of Israel and Zion (Hossfeld \& Zenger 2002:337). The psalmist asks God to be gracious to Zion and to rebuild the walls of Jerusalem, so that the people may sacrifice to give Him joy. As the expectation of fortune and divine favour was a reality in the Solomonic period, so this final part of the prayer presents an expectation of the future facing the early postexilic community of Israel. This Israel can trustfully await the day when God will also bestow his grace, loving kindness and mercy on Zion.

What is true of the individual also applies to the people of God (Tate 1990:32;). The psalm wants to confirm that the experience of the psalmist is also applicable to Israel. Possibly this may be a prayer for the Israelite community of faith who lived just after the exile and who no doubt wrestled with their awareness of their own sense of guilt, sin and shame. They realized that their own sin was the cause for their exile. Zion was destroyed and Jerusalem's walls were leveled. There was no official sacrificial system or house of prayer. During this time the people of Zion were overwhelmed by depression.

The prayer for Zion therefore articulates the expectancy that Zion as the city of God may in the future carry God's justice to all nations (Is 1:26). As a light to the nations, Israel, through its praise of God and by its instruction in His ways, would make Zion the centre from which God's justice flowed outwards to all the people of the world (Is 2:2-4; Mi 4:1-2).

\section{CONCLUDING REMARKS}

Psalm 51 is a prayer of penitence in which the suffering sinner prays to God for the forgiveness of his transgressions. He calls to God as the God of Israel's history as the One whom we can trust. God will deal with his guilt justly. Overwhelmed by his own guilt the psalmist begs God to wash and cleanse him and that his sin and guilt may thus be removed. In his heart he knows that he has he has sinned against God. That is why he asks God to create a pure heart for him that he may make the right decisions in his life. It will indeed involve a new creation. In addition, he prays for a steady and willing spirit, which 
must be bound to God's own spirit. From gratitude to God's act of salvation, the psalmist offers his sacrifice of thanksgiving, which is accompanied by a broken spirit and a contrite heart. With this humiliation and sorrow, the roots of which are firmly anchored in God's grace, loving kindness and mercy, the process of reconciliation between the psalmist and God achieves a special depth.

The experience of the individual is also applicable to all the people of Israel. Thus, the forgiveness that the psalmist receives creates a sense of hope and expectancy in the depressed post-exilic community that God's salvific love and grace may also allow for the restoration of Zion. This is the motivation behind the concluding prayer for the reparation of Zion and Jerusalem. As the psalmist shares the joy of God's ways with sinners, so Zion, as the city of the God of justice will become a light for the nations when the will of the Lord is taught therein and his judgment flows therefrom.

For the Christian believer, this prayer of penitence attains a special dimension when the light of the Jesus narratives shines upon it. There is no need to force a christological interpretation on Psalm 51, since we should rather think of the Jesus narratives as being the confirmation of the grace, loving kindness and mercy of God as witnessed to in the Old Testament Scriptures, e.g. the Psalms of Penitence.

Psalm 51 offers the believing person hopeful perspectives with which he or she may not only discover the process of repentance penitence - forgiveness - renewal - reconciliation, but also follow in the footsteps of the psalmist by repeating these utterances.

\section{Consulted literature}

Bardtke, H 1989. Psalmen, in: Gutbrod, K \& Kücklich, R (Hrsg), Calwer Bibellexikon. Sechste Auflage. Stuttgart: Calwer Verlag, 1082-1085.

Deissler, A 1964. Die Psalmen. Düsseldirf: Patmos Verlag.

Fischer, B 1958. Busspsalmen, in: Höfer, J \& Rahner, K (Hrsg), Lexikon für Theologie und Kirche. Zweiter Band. Freiburg:Herder, 822-823.

Gerstenberger, E 1988. Psalms. Part I. With an introduction to cultic poetry (FOTL XIV). Grand Rapids (MI): Eerdmans. 
Gispen, W H (ea) 1975. Boeteprediking, in:; Gispen, WH ea. (reds), Bijbelse Encyclopedie. Eerste Deel. Kampen: Kok, 168.

Hossfeld, F-L \& Zenger, E 2002. Die Psalmen: Psalm 51-100 (NEB). Würzburg: Echter Verlag

McKeating, H 1965. Divine forgiveness in the psalms, Scottish Journal of Theology 18, 69-83.

Millard, M 1994. Die Komposition des Psalters. Ein formgeschichtlicher Ansatz. FAT 9. Tübingen: Mohr (Siebeck).

Murphy, R E 1967. Penitential psalms, in: Whalen, J P \& O’ Boyle, P A, New Catholic Encyclopedia. Volume XI. San Franciso/ Toronto/ London/ Sydney: McGraw Hill Book Company, 85-86.

Olivier, H \& Swanepoel, P 1997. Eerlik met God in die krisisuur. 'n Bespreking van die aard van die klaagpsalms, In die Skriflig 31(3), 199-214.

Press, R 1969. Boetpsalmen, in: Reicke, B \& Rost, L (eds), Bijbels-Historisch Woordenboek I. Utrecht/Antwerpen: Het Spectrum, 276.

Tate, M E 1990. Psalms 51-100 (WBC). Dallas, Texas: Word Books.

Terrien, S 2003. The Psalms. Strophic structure and theological commentary. Grand Rapids (MI): Eerdmans.

Vorgrimler, H 2000. Busse, in: Vorgrimler, H (Hrsg), Neues Theologisches Wörterbuch. Freiburg (Breslau): Herder, 106-107.

Weber, B 2001. Werkbuch Psalmen I. Die Psalmen 1 bis 72. Stuttgart/ Berlin/ Köln: Kohlhammer.

Welten P 1993. Busse - Altes Testament, in: Balz HR ea (Hrsg), Theologische Realenzyklopädie. Band VII. Berlin/New York: Walter de Gruyter, 433439. 